\title{
First ex situ outplanting of the habitat-forming seaweed Cystoseira amentacea var. stricta from a restoration perspective
}

\author{
Gina De La Fuente ${ }^{\text {Corresp., } 1}$, Mariachiara Chiantore ${ }^{1}$, Valentina Asnaghi ${ }^{1}$, Sara Kaleb ${ }^{2}$, Annalisa Falace ${ }^{2}$ \\ 1 Department of Earth, Environment and Life Sciences, University of Genoa, Genoa, Italy \\ 2 Department of Life Sciences, University of Trieste, Trieste, Italy \\ Corresponding Author: Gina De La Fuente \\ Email address: gina.delafuente@edu.unige.it
}

In the Mediterranean Sea, brown algae belonging to the Cystoseira genus play a valuable role as foundation species. Due to evidences of regression/loss of the habitats of these species caused by the interplay of human and climatic disturbances, active restoration measures have been encouraged by EU regulations. In particular, nondestructive restoration techniques, which avoid the depletion of threatened species in donor populations, are strongly recommended. In the framework of the EU project ROCPOP-Life, the first ex situ outplanting experience of Cystoseira amentacea var. stricta has been implemented in the Cinque Terre Marine Protected Area (northwestern Mediterranean). A total of 400 clay tiles, hosting approximately $3 \mathrm{~mm}$-long germlings of $C$. amentacea, were fixed to the rocky shore with screws: the tiles were monitored for the next two months by photographic sampling, and survival (presence/absence of juveniles on the tiles), cover and growth were assessed. Additional sampling was performed 6 months after tile deployment, after which an unprecedented storm surge severely affected the restoration performance. After two months, over $40 \%$ of the tiles were covered with Cystoseira juveniles, which reached approximately $8 \mathrm{~mm}$ in total length. The tiles that survived the storm hosted 3-6 cm-long juveniles. The high cover (> 25\%), assuring moisture and shading, and the appropriate size of the juveniles, to avert micro-grazing, at time of deployment were key to the survival and growth of the outplanted juveniles, increasing the potential for restoration success. Our findings show that outplanting of midlittoral canopyforming species is a feasible approach for restoration efforts, with particular attention given to the early phases: i) laboratory culture, ii) transport, and iii) juvenile densities. These results are strongly encouraging for the implementation of restoration actions for Cystoseira amentacea on a large scale, in light of EU guidelines. 


\section{First ex situ outplanting of the habitat-forming}

\section{2 seaweed Cystoseira amentacea var. stricta from a}

3 restoration perspective

Gina De La Fuente ${ }^{1}$, Mariachiara Chiantore ${ }^{1}$, Valentina Asnaghi ${ }^{1}$, Sara Kaleb ${ }^{2}$, Annalisa Falace ${ }^{2}$

${ }^{1}$ Department of Earth, Environment and Life Sciences, University of Genova, Genova, Italy

Corresponding Author:

Gina De La Fuente ${ }^{1}$

Corso Europa 26, Genova, 16132, Italy

Email address: gina.delafuente@edu.unige.it

\section{Abstract}

In the Mediterranean Sea, brown algae belonging to the Cystoseira genus play a valuable role as foundation species. Due to evidences of regression/loss of the habitats of these species caused by the interplay of human and climatic disturbances, active restoration measures have been encouraged by EU regulations. In particular, nondestructive restoration techniques, which avoid the depletion of threatened species in donor populations, are strongly recommended. In the framework of the EU project ROCPOP-Life, the first ex situ outplanting experience of Cystoseira amentacea var. stricta has been implemented in the Cinque Terre Marine Protected Area (northwestern Mediterranean). A total of 400 clay tiles, hosting approximately $3 \mathrm{~mm}$-long germlings of $C$. amentacea, were fixed to the rocky shore with screws: the tiles were monitored for the next two months by photographic sampling, and survival (presence/absence of juveniles on the tiles), cover and growth were assessed. Additional sampling was performed 6 months after tile deployment, after which an unprecedented storm surge severely affected the restoration performance. After two months, over $40 \%$ of the tiles were covered with Cystoseira juveniles, which reached approximately $8 \mathrm{~mm}$ in total length. The tiles that survived the storm hosted 3-6 cm-long juveniles.

The high cover (>25\%), assuring moisture and shading, and the appropriate size of the juveniles, to avert micro-grazing, at time of deployment were key to the survival and growth of the outplanted juveniles, increasing the potential for restoration success.

Our findings show that outplanting of midlittoral canopy-forming species is a feasible approach for restoration efforts, with particular attention given to the early phases: i) laboratory culture, ii) transport, and iii) juveniles densities. These results are strongly encouraging for the implementation of restoration actions for Cystoseira amentacea on a large scale, in light of EU guidelines. 


\section{Introduction}

41 Approximately thirty-five percent of brown algae species (Laminariales and Fucales; Guiry and

42

43

44

45

46

47

48

49

50

51

52

53

54

55

56

57

58

59

60

61

62

63

64

65

66

67

68

69

70

71

72

73

74

75

76

77

78 which enhance habitat complexity, biodiversity, ecosystem functioning and the natural capital of littoral ecosystems (Thompson et al., 1996; Christie et al., 2007; Airoldi et al., 2015). Kelp forests (i.e. Macrocystis, Lessonia and Laminaria) constitute one of the most diverse and productive ecosystems distributed worldwide (Steneck et al., 2002). In the Mediterranean Sea, some Laminariales (e.g., Laminaria and Sacchoriza) and Fucales (e.g., Sargassum and Cystoseira) also play a role as foundation species in some specific locations, but the canopyforming brown algae of the Cystoseira genus are the most important because they are widespread in this biogeographic region (Rodriguez-Prieto et al., 2013). However, they are exposed to multiple disturbances that cause a decline in their abundance in many coastal areas (Airoldi et al., 2008; Mineur et al., 2015). The main pressures affecting the valuable ecosystems formed by Cystoseira are sedimentation (Perkol-Finkel \& Airoldi, 2010), low water quality (Arévalo et al., 2007; Sales et al., 2011), anthropization (Mangialajo et al., 2008) and overgrazing (Sala et al., 1998; Hereu, 2004; Vergés et al., 2014).

Several studies conducted in the Mediterranean have reported on the past and the present distribution and abundance of Cystoseria canopies (Thibaut et al., 2014; Mancuso et al., 2018), detecting regressions or losses caused by the above mentioned factors (Cormaci and Furnari, 1999; Thibaut et al., 2005; Falace et al., 2010; De La Fuente et al., 2018). Their natural recovery, in the absence of adults, is hampered by the very limited dispersal of Cystoseira species due to the rapid fertilization of their large eggs and zygote sinking (Falace et al., 2018).

In this framework, active marine restoration is strongly encouraged to prevent the loss of the valuable habitats formed by Cystoseira species that enhance biodiversity and preserve ecosystem functions and services (i.e., EU Biodiversity Strategy 2020).

Three different restoration techniques have been implemented in the Mediterranean Sea for Cystoseira species: i) transplanting juveniles or adults (Falace et al., 2006; Susini et al., 2007), ii) positioning fertile receptacles in the target area (in situ; Verdura et al, 2018) or iii) outplanting juveniles cultured in the laboratory along the shore (ex situ; Sales et al., 2011; Verdura et al. 2018). The latter two techniques are strongly recommended for the restoration of threatened species to avoid the depletion of natural donor populations (Falace et al., 2018). Active restoration actions must be implemented depending on the biological traits of the target species (i.e., reproductive strategy) and the environmental characteristics (i.e., depth and hydrodynamics). The in situ technique seems to be especially suitable for species with high dispersal capacity (e.g.,: kelps; Reed et al., 1988; Gaylord et al., 2002), while the ex situ technique is more appropriate for species with a low dispersal capacity (e.g., C. amentacea; Mangialajo et al., 2012). Both techniques have been recently validated for a shallow species $(C$. barbata; Verdura et al., 2018) living in low hydrodynamic conditions, but at present, such approaches have never been tested for the midlittoral habitat.

PeerJ reviewing PDF | (2019:02:34961:2:1:NEW 4 Jun 2019) 
79 The aim of this study was to apply the ex situ technique (outplanting) to midlittoral Cystoseira

80

81

82

83

84

85

86

87

88

89

90

91

92

93

94

95

96

97

98

99

100

101

102

103

104

105

106

107

108

109

110

111

112

113

114

115

116

117

118

amentacea var. stricta Montagne (hereafter $C$. amentacea), in the Ligurian Sea (northwestern

Mediterranean), assessing its survival, cover and growth in the first, most critical, months

following implementation. The outplanting was performed in the Cinque Terre Marine Protected Area (Cinque Terre MPA), where, at present, only the more tolerant congener C. compressa is found in continuous and discontinuous belts (Asnaghi et al., 2009; De La Fuente et al., 2018). Here, C. amentacea is presently missing as well as across the whole easternmost side of the Ligurian coastline starting from Punta Manara, which is approximately $20 \mathrm{~km}$ northwest of the Cinque Terre MPA (authors' personal observation). This species was recorded in the area until the end of the 19th century (authors' personal observation through herbarium records, De La Fuente et al., 2018) and its disappearance can be explained by habitat fragmentation due to coastal developments, water pollution and high sediment loads. Such stressors were related to the intense excavating activities that were carried out to extract construction material (mostly for building railways and highways in the area), which occurred in the first half of the 20th century. Even though such disruptive activities have largely been reduced in recent decades, with significant changes in the riverine basin and sediment load to the sea, and a MPA was established (1997), this sensitive species is still absent along these stretches of coastline. This is likely due to its above mentioned low dispersal capacity $(<1 \mathrm{~m}$, Johnson \& Brawley, 1998; Mangialajo et al., 2012) which hampers the natural recovery of this species, in addition to other local factors, such as mussel farming (as a result of competition for space with the settled mussel juveniles).

The effectiveness of the ex situ approach over the first six months following its implementation, was assessed in terms of the presence, cover and growth of the outplanted C. amentacea juveniles in the framework of the EU project ROCPOP-Life.

\section{Materials \& Methods}

\section{Study sites}

The ex situ outplanting of the midlittoral species C. amentacea was performed in summer 2018 following a nondestructive strategy, with apical fronds (ca. $3 \mathrm{~cm}$ in length) holding mature receptacles collected in June from a healthy population located in the Portofino MPA (donor site) along a 200-meters stretch of coastline. After a laboratory culturing period, the juveniles were transplanted into the Cinque Terre MPA (receiving site; approximately $80 \mathrm{~km}$ from the donor site). Both MPAs are located in the Ligurian Sea, northwestern Mediterranean (Fig. 1). The sites are characterized by a tide in the range of $30 \mathrm{~cm}$ (under these conditions, barometric pressure effects may have a dominant effect on the water level) and an average spring temperature of 20

${ }^{\circ} \mathrm{C}$. After sampling, the apices were gently cleaned with tweezers and rinsed with filtered seawater to remove adherent biofouling and detritus. Then, the apices, which were wrapped in seawaterwetted towels, were delivered within 24 hours to the laboratory in Trieste (northeastern Italy; Fig. 1) under dark, cold and humid conditions for culturing in environmentally controlled rooms.

\section{Laboratory ex situ cultivation}

Peer) reviewing PDF | (2019:02:34961:2:1:NEW 4 Jun 2019) 
119 Three apices with mature receptacles (additionally cleaned with a brush and rinsed with

120

121

122

123

124

125

126

127

128

129

130

131

132

133

134

135

136

137

138

139

140

141

142

143

144

145

146

147

148

149

150

151

152

153

154

155

156

157

158

autoclaved seawater) were placed on each substrate constituted of a rough round tiles composed of clay ( $4.5 \mathrm{~cm}$ in diameter) with a $0.6 \mathrm{~cm}$ hole at the center to fix the tile onto the rocks with a screw. On the next day, the fertile apices were removed, and the zygotes attached to the tiles were cultured over a three-week period $(\approx 450$ tiles $)$.

Temperature $\left(+20^{\circ} \mathrm{C}\right)$ and photoperiod $\left(125 \mu \mathrm{moL}\right.$ photons $\left.\mathrm{m}^{-2} \mathrm{~s}^{-1}\right)$ were selected according to the protocol provided in Falace et al. (2018). Von Stosch's enriched filtered seawater (VSE) was used as the culture medium to accelerate the culturing time for the $C$. amentacea individuals to reach a greater size at the time of outplanting (Falace et al., 2018). The medium was enriched with antibiotic $\left(2 \mu \mathrm{L}\right.$ of amikacin sulphate and $500 \mu \mathrm{g}$ of ampicillin sodium $\mathrm{L}^{-1}$ of culture medium) and $\mathrm{GeO}_{2}$ (Falace et al., 2006) to prevent bacterial and diatom growth. The culture medium in the aquaria was renewed every 3 days to minimize any possible effects of nutrient limitation and was continuously aerated by bubbling and water multifunction pumps $(\approx 300 \mathrm{~L}$ hour ${ }^{-1}$ flow) to increase oxygenation and hydrodynamics.

After 24 days of controlled growth in the Trieste laboratory, photographs were taken (17th July; 160 random tiles) in order to assess the percent cover and juvenile length.

\section{Outplanting and monitoring in the field}

On 19th July 2018 the tiles were transported to Cinque Terre MPA. All the tiles were carefully placed in small boxes filled with filtered seawater, which were placed in a large insulated container that was maintained at a cool temperature with icepacks. The container was transported by car with an air conditioner ( $\approx 7$-hours trip, temperature in the range of $\left.20-22^{\circ} \mathrm{C}\right)$ to the receiving site, where the boxes were stored in an air-conditioned room overnight $\left(\right.$ at $\left.22^{\circ} \mathrm{C}\right)$.

On the next day (20th July 2018, Time 0), the tiles were carefully transported to the field, using a rubber boat. Eight patches (Fig. S1) were established in the previous weeks: 50 holes were drilled in each patch and screws placed within them in advance. On the day of implementation, the tiles were quickly screwed to the rocks. Overall, the deployment of 400 tiles was performed in approximately 5 hours. On the days of transport and deployment, the air temperature was in the range of $23-27^{\circ} \mathrm{C}$ and the sea temperature was in the range of $25-26^{\circ} \mathrm{C}$.

Monitoring of the clay tiles started on the same day (Time 0 ) and continued over the following 2 months: July 27th (Time 1), August 6th (Time 2), August 29th (Time 3) and September 27th (Time 4). During each sampling time, photos were taken of a randomly selected 20 of the 50 clay tiles in each patch. The photos were analysed in the lab using Image $J$ to assess percent cover and survival (i.e., overall presence/absence of juveniles). Thallus length was measured for 40 randomly selected individual specimens with ImageJ at each sampling time except Time 5 (measured in the field).

Additional sampling was performed 4 months later (Time 5). This sampling occurred after an unprecedented storm surge that affected the Ligurian Sea at the end of October 2018 (ANSA, 2018; The MediTelegraph, 2018), which caused great destruction along the entire Ligurian coastline, with estimated damages of hundreds of millions of euros. This storm caused the

Peer) reviewing PDF | (2019:02:34961:2:1:NEW 4 Jun 2019) 
159 destruction of entire harbors and ships in marinas, particularly along the eastern side of the 160 Ligurian coast. Huge damage was reported among the shallow benthic communities, particularly 161 the Posidonia meadows (Il Secolo XIX, 2018). Because most of the tiles were detached by this 162 unprecedented event ( $180 \mathrm{~km}$ hour $^{-1}$ winds and waves greater than 10 meters high), it was not 163 possible to quantitatively assess restoration performance in terms of percent cover but only in 164 terms of juvenile growth (length) on the 16 tiles with $C$. amentacea juveniles of the 165 approximatively 69 remaining tiles.

166

167

168

169

170

\section{Data analysis}

One-way ANOVA was applied to assess possible differences in the percent cover of the juveniles on the tiles when leaving the laboratory versus at the time of the deployment (Time 0 ) after arcsin transformation of the data and verification of assumptions (normality using the Shapiro-Wilk test and homoscedasticity using Bartlett's test).

The effect of percent cover at the time of deployment was assessed using a generalised linear model (GLM) for both the percent cover (family=quasibinomial) and the presence/absence (family=binomial) of juveniles on the tiles at Time 4, using the "cover class" of each patch at the start of the experiment as the predictor variable. Patches were classified according to 3 "cover classes" (based on the percent cover at the start of the experiment): Low (18.2 \pm 1.6 , avg $\pm \mathrm{SE}$; patches 2, 3 and 5), Medium (25.0 \pm 2.1 ; patches 1, 7 and 8) and High (32.2 \pm 2.5 ; patches 4 and 6). Statistical analyses were performed with the free software R (R Development Core Team 2015, version 3.2.3) using the stats package.

\section{Results}

The juveniles were $2.65 \pm 0.05 \mathrm{~mm}$ (avg $\pm \mathrm{SE}$ ) in length when they were transported to the receiving site. The percent cover on the tiles measured at Time 0 was compared with that at the time they left the laboratory ( 3 days before) to assess the effect of transport (Fig. 2). The percent cover in the laboratory and in outplants at Time 0 did not significantly differ (one-way ANOVA; $\mathrm{p}=0.327$ ).

At the start of tile deployment, the average percent cover of the juveniles was $24.22( \pm 1.24 \%)$.

The percent cover data of the juveniles on the tiles in the eight patches over time (Time 0 to Time 4) are reported in Fig. 3. All patches showed a sharp decline in percent cover from Time 0 to Time 1 due to the predictable loss of some juveniles in the field. Some patches clearly showed lower average values of cover at Time 0 (ranging from $15.88 \pm 2.63$ in patch 2 to $32.48 \pm 2.59$ in patch 6; avg $\pm \mathrm{SE}$ ), and this difference in cover at the start of the experiment affected the survival and growth of the juveniles over time (Fig. 3). In the patches characterised by higher cover of juveniles at the beginning of the experiment (patches 4 and 6), after the first decline, cover increased on the following sampling dates (reaching $27.37 \pm 2.63$ and $11.65 \pm 3.99$ at Time 4 in patches 4 and 6, respectively) because of the growth of the juveniles (Fig. 3 and 4), while the patches characterized by lower cover showed a general decreased in percent cover (reaching 3.06 \pm 1.55 and $4.85 \pm 2.88$ at Time 4 in patches 2 and 3 respectively; juveniles lost in patch 5). The 
199 GLM for the percent cover on the tiles at Time 4 showed significant differences among the 200 classes $(\mathrm{p}=0.0143)$. The Low class was significantly differed from the others, while the Medium 201 class did not differ from the High class (Table 1).

202 The good performance of the outplanting, at least in the early phases, is confirmed by the 203 assessment of the percentage of tiles with the presence of juveniles (Fig. 5). In fact, from Time 0 204 to Time 1, this percentage changed from $100 \%$ to $88 \%$ and was still over $40 \%$ after two months 205 (Time 4). Similar to cover, survival also differed in the patches characterized by higher cover of 206 juveniles at the start of the experiment. In fact, the GLM on the presence/absence of juveniles on 207 the tiles at Time 4 using the cover class of each patch at the start of the experiment as a predictor 208 variable showed significant differences among the classes $(p=0.00161)$. The Low class significantly differed from the others, while the Medium class did not differ from the High class

210

211

212

213 (Table 1): this implies that cover at the start of the experiment greater than $25 \%$ is required for a good outplanting performance.

214 The growth of the ouplanted juveniles over time is shown in Fig. 6 and 7. The thallus length of the juveniles of $C$. amentacea was mostly under $6 \mathrm{~mm}$ at Time $0(3.22 \pm 0.08$, avg $\pm \mathrm{SE})$, Time 1 $(3.73 \pm 0.10)$ and Time $2(4.67 \pm 0.13)$. At Time $3(6.02 \pm 0.18)$ and Time 4 , juveniles grew to up to $11 \mathrm{~mm}$, with a higher number of individuals $8-10 \mathrm{~mm}$ in size at Time $4(8.03 \pm 0.22)$. After 217 2019).

\section{Discussion}

220 Outplanting represents an innovative technique for restocking of brown canopy-forming macroalgae (Falace et al., 2018), although its implementation consists of a set of delicate steps: i)

222

223 fertile material collection, ii) culturing of juveniles in the lab, iii) transport of juveniles to the field and iv) attachment of the juveniles to the rocky shore. In addition to the multiple set of phases, this technique needs to be adapted according to target species-specific requirements in the different phases of implementation.

226

227

228

229

230

231

232

233 The lab culture process involves several issues related to the wellness of the sensitive embryo stage. The thorough cleaning of the fertile apices before and after transport to the lab facilities to reduce epiphyte outbreaks and the presence of grazers helps to increase the chance of good performance. The $C$. amentacea embryos were cultured under their optimal temperature and light intensity conditions to maximize the yield (Falace et al., 2018), which can also unfortunately enhance spores, propagules and bacteria proliferation. The implemented culture setting (e.g., the addition of antibacterial solutions and enhanced hydrodynamics) preserved the culture in good conditions, with healthy juveniles larger $(2.65 \mathrm{~mm})$ than those in previous Cystoseira restoration studies being obtained in only three weeks: C. amentacea (three weeks $-1.38 \mathrm{~mm}$; Falace et al., 2018) and C. barbata (one month 200- $400 \mu \mathrm{m}$; Verdura et al., 2018). Furthermore, the length recorded one month after outplanting $(6.02 \mathrm{~mm}$; Fig. 6$)$ is similar or even slightly larger than that recorded in a previous study on C. amentacea $(4.73 \mathrm{~mm}$; Falace et al., 2018) because the outplanting size was also larger in the present study. 
239 The transport of early life stages from the nursery facility to the receiving site, which may be 240 located a large distance away, as in this case $(\approx 600 \mathrm{~km})$, was found to not affect their fitness. 241 The results show no significant differences in the percent cover of juveniles before and after 242 transport. The cover of the juveniles on tiles at the time of arrival at the receiving site was even 243 slightly greater than that when leaving the nursery facility (before transport $-21.6 \%$, after

244 transport-24.2\%; Fig. 2). This result was obtained maintaining a good temperature range (20-

245

246

247

248

249

250

251

252

253

254

255

256

257

258

259

260

261

262

263

264

265

266

267

268

269

270

271

272

273

274

275

276

277

278 $22^{\circ} \mathrm{C}$ ) during transport and during the attachment of the clay tiles in the field (outplanting action). Due to the high numbers, the clay tiles were transported, by rubber boat in cooled boxes to the rocky shore in several times over the course of the same day to prevent solar heat stress during attachment.

The attachment technique applied in this study, using pre-established screws instead of epoxy putty, which is generally used for both adults and juveniles (Susini et al., 2007; Whitaker et al., 2010; Perkol-Finkel et al., 2012; Verdura et al., 2018), increases the effectiveness of outplanting by reducing the time spent for attachment (the deployment of 400 tiles was performed in 5 hours by 6 people) and the possible dislodgement by wave action on the day of deployment or the following days (Susini et al., 2007). This method additionally minimizes the aesthetic and environmental impacts on the rocky shores and is reported to reinforce attachment, preventing the possible dislodgement of the clay tiles by wave action, as in the case of Lessonia nigrescens restoration (Vázquez and Tala, 1995). This is particularly important for midlittoral species living under high hydrodynamic conditions, as in the case of $C$. amentacea. In our study, we observed very positive results over the first 2 months (with the overall dislodgement of approximately 39 tiles). Unfortunately, the experiment was strongly affected by an unprecedented storm surge (winds over $170 \mathrm{~km}$ hour $^{-1}$ and significant wave height of $6 \mathrm{~m}$ and maximum waves of $10 \mathrm{~m}$ height, over approximately 12 hours). This storm surge caused the destruction of entire harbors and ships in marinas and caused great damage to the shallow benthic communities. This event caused a large loss of tiles: 69 tiles survived the storm out of the 361 reported at Time 4 . This means that, notwithstanding the exceptional strength of the storm, $20 \%$ survived the event, although only 16 of them hosted juveniles. Overall, the attachment method used in this study seems to be not only more environmentally friendly than the epoxy putty attachment method but also quite resistant to wave action. The screws themselves were not at all removed from the shore.

In addition to providing information for the optimization of culture and transport/outplanting techniques, our results stress the relevance of juvenile cover on the tiles. Relatively high cover (greater than $25 \%$ of the tile covered at the time of deployment) ensures the survival of the outplanted juveniles (Table 1; Fig. 4). Midlittoral species are exposed to high solar heat and desiccation stress; therefore, a higher percentage of cover allows moisture and shading to be retained, enhancing the development of early juveniles (Brawley and Johnson,1991; Dudgeon and Petraitis, 2005).

Another key issue regulating outplanting success is grazing, which was reported in previous studies, e.g., on Sargassum species, where did not obviously affect the development of the 
279

280

281

282

283

284

285

286

287

288

289

290

291

292

293

294

295

296

297

298

299

300

301

302

303

304

305

306

307

308

309

310

311

312

313

314

315

316

317

318

outplanted juveniles in order to establish population in the restoration site, because of the low density of major grazers ( 7 individuals $/ 0.25 \mathrm{~m}^{2}$, Yu et al., 2012) and the use of cages to protect juveniles from grazing, until reaching a suitable grazing free size (Yoon et al., 2014). In this study, we did not formally test the effect of grazing, but we can exclude it having a relevant role. No grazers were observed crawling on the tiles at the time of sampling or in the photographs. In terms of small grazers (mostly small amphipods and isopods), their potential abundance may be estimated from the paper by Thrush et al. (2011), which reports densities of grazing crustaceans in the range of 9 individuals $/ 20 \mathrm{~cm}^{2}$ in the area, which is likely not high enough to exert a strong grazing effect. Furthermore, the tiles were located relatively high on the shore compared to the mean sea water level, and this could actually prevent grazing by fish and sea urchins, which are generally considered the most relevant herbivores (Ling et al., 2015; Gianni et al., 2017).

\section{Conclusions}

Our findings show that outplanting midlittoral canopy-forming species is a feasible approach for restoration efforts. In particular, our study addressed the early steps of restoration and provides information on best practices for the outplanting phases of laboratory culture, transport and reintroduction in the natural environment.

The laboratory culture phase requires appropriate species-specific protocols to reduce outbreaks of epiphytes, obtain high cover and a large size of the juveniles for field deployment, and increase the potential for restoration success. The use of an appropriate culture medium, the addition of an antibacterial solution and thorough fertile material cleaning are relevant elements likely to guarantee good culture performance and obtain high densities of healthy embryos. The feasibility of large distance transport from the laboratory to the field has been remarkably shown, providing a potential option for replication also on a large scale.

The applied screw attachment technique was found to be effective in terms of increasing the efficiency of tile deployment and resistance to dislodgement, particularly in the early stages of restoration, when the traditional epoxy putty technique may be strongly affected by wave action, which is particularly relevant for midlittoral species

These results are strongly encouraging for the implementation of restoration actions of canopyforming species on a large scale, in light of EU guidelines.

\section{Acknowledgements}

We would like to thank the contributions of all colleagues and students who helped in the field and during samples processing: Saul Ciriaco (Shoreline Soc. COOP), Sara Menon (Shoreline Soc. COOP), Marco Segarich (Shoreline Soc. COOP), Massimo Andreoli (Cinque Terre Marine Protected Area), Enrico Agostini (Nemo-Italia), Davide Monteggia (University of Genoa), Maria Paola Ferranti (University of Genoa), Lorenzo Meroni (University of Genoa), Greta Fallanca (University of Genoa), Francesca Piga (University of Genoa). We are sincerely grateful to the referees Enric Ballesteros, Kiran Liversage and an anonymous third referee, as well as to the editor Anastazia Banaszak for improving this manuscript with their valuable comments. 
320

321

322

323

324

325

326

327

328

329

330

331

332

333

334

335

336

337

338

339

340

341

342

343

344

345

346

347

348

349

350

351

352

353

354

355

356

357

358

359

\section{References}

Airoldi L, Balata D, Beck MW. The gray zone: relationships between habitat loss and marine diversity and their applications in conservation. J Exp Mar Bio Ecol. 2008; 366(1-2): 8-15. https://doi.org/10.1016/j.jembe.2008.07.034

Airoldi L, Ballesteros E, Buonuomo R, van Belzen J, Bouma TJ, Cebrian E, De Clerk O, Engelen, AH, Ferrario F, Fraschetti S, Gianni F, Guidetti P, Ivesa L, Mancuso FP, Micheli F, Perkol-Finkel S, Serrao EA, Strain EM, Mangialajo L. Marine forests at risk: solutions to halt the loss and promote the recovery of Mediterranean canopy-forming seaweeds. In 5 th Mediterranean Symposium on Marine Vegetation. 2015.

ANSA. Storm death toll up to 11, Liguria on its knees. [cited 2018 Oct 30]. Available from: http://www.ansa.it/english/newswire/english_service/2018/10/30/ansa-storm-death-toll-up-to-11liguria-on-its-knees 0973b7e8-492d-4802-8e16-9820abe65783.html

Arévalo R, Pinedo S, Ballesteros E. Changes in the composition and structure of Mediterranean rocky-shore communities following a gradient of nutrient enrichment: descriptive study and test of proposed methods to assess water quality regarding macroalgae. Mar Poll Bull. 2007; 55(1-6): 104-113.

Asnaghi V, Chiantore M, Bertolotto RM, Parravicini V, Cattaneo-Vietti R, Gaino F, Moretto P, Privitera D, Mangialajo L. Implementation of the European Water Framework Directive: Natural variability associated with the CARLIT method on the rocky shores of the Ligurian Sea (Italy).

Mar Ecol. 2009; 30(4): 505-513. https://doi.org/10.1111/j.1439-0485.2009.00346.x

Brawley SH, Johnson LE. Survival of fucoid embryos in the intertidal zone depends upon development stage and microhabitat. J Phycol. 1991; 27(2): 179-186.

https://doi.org/10.1111/j.0022-3646.1991.00179.x

Christie H, Jørgensen NM, Norderhaug KM. Bushy or smooth, high or low; importance of habitat architecture and vertical position for distribution of fauna on kelp. J Sea Res. 2007; 58(3): 198-208. https://doi.org/10.1016/j.seares.2007.03.006

Cormaci M, Furnari G. Changes of the benthic algal flora of the Tremiti Islands (southern Adriatic) Italy. In Sixteenth International Seaweed Symposium. Springer, Dordrecht. 1999; 75-79.

De La Fuente G, Chiantore M, Gaino F, Asnaghi V. Ecological status improvement over a decade along the Ligurian coast according to a macroalgae based index (CARLIT). PLoS ONE. 2018; 13(12): e0206826. https://doi.org/10.1371/journal.pone.0206826 
360 Dudgeon S, Petraitis PS. First year demography of the foundation species, Ascophyllum

361

362

363

364

365

366

367

368

369

370

371

372

373

374

375

376

377

378

379

380

381

382

383

384

385

386

387

388

389

390

391

392

393

394

395

396

397

398

399

400

nodosum, and its community implications. Oikos. 2005; 109(2): 405-415.

https://doi.org/10.1111/j.0030-1299.2005.13782.x

Falace A, Zanelli E, Bressan G. Algal transplantation as a potential tool for artificial reef management and environmental mitigation. Bull Mar Sci. 2006; 8: 161-166.

Falace A, Alongi G, Cormaci M, Furnari G, Curiel D, Cecere E, Petrocelli A. Changes in the benthic algae along the Adriatic Sea in the last three decades. Chem Ecol. 2010; 26(1): 77-90. https://doi.org/10.1080/02757541003689837

Falace A, Kaleb S, De La Fuente G, Asnaghi V, Chiantore M. Ex situ cultivation protocol for Cystoseira amentacea var. stricta (Fucales, Phaeophyceae) from a restoration perspective. PloS ONE. 2018; 13(2): e0193011. https://doi.org/10.1371/journal.pone.0193011

Gaylord B, Reed DC, Raimondi PT, Washburn L, McLean SR. A physically based model of macroalgal spore dispersal in the wave and current-dominated nearshore. Ecology. 2002; 83(5): 1239-1251. https://doi.org/10.1890/0012-9658(2002)083[1239:APBMOM]2.0.CO;2

Gianni F, Bartolini F, Pey A, Laurent M, Martins GM, Airoldi L, Mangialajo L. Threats to large brown algal forests in temperate seas: the overlooked role of native herbivorous fish. Scientific Reports.2017; 7: 6012.

Guiry MD, Guiry GM. 2019. AlgaeBase. World-wide electronic publication, National University of Ireland, Galway. http://www.algaebase.org; searched on 04 February 2019.

Hereu B. The role of trophic interactions between fishes, sea urchins and algae in the northwestern Mediterranean rocky infralittoral. PhD thesis. University of Barcelona. 2004.

IL Secolo XIX. Mareggiata, una catastrofe che ha sconvolto i fondali di Portofino. [cited 2018 Nov 20]. Available from: https://www.ilsecoloxix.it/p/italia/2018/11/20/ADqanphCmareggiata_sconvolto_catastrofe.shtml

Johnson LE, Brawley SH. Dispersal and recruitment of a canopy-forming intertidal alga: the relative roles of propagule availability and post-settlement processes. Oecologia. 1998; 117(4): 517-526. http://dx.doi.org/10.1007/s004420050688.

Ling SD, Scheibling RE, Rassweiler A, Johnson CR, Shears N, Connell SD, Salomon AK, Norderhaug KM, Pérez-Matus A, Hernández JC, Clemente S, Blamey LK, Hereu B, Ballesteros E, Sala E, Garrabou J, Cebrian E, Zabala M, Fujita D, Johnson LE. Global regime shift dynamics of catastrophic sea urchin overgrazing. Philos. T. Roy. Soc. B. 2015; 370: 20130269.

Peer) reviewing PDF | (2019:02:34961:2:1:NEW 4 Jun 2019) 
401 Mangialajo L, Chiantore M, Cattaneo-Vietti R. Loss of fucoid algae along a gradient of 402 urbanisation, and structure of benthic assemblages. Mar Ecol Prog Ser. 2008; 358: 63-74.

403 https://doi.org/10.3354/meps07400

404

405

406

407

408

409

410

411

412

413

414

415

416

417

418

419

420

421

422

423

424

425

426

427

428

429

430

431

432

433

434

435

436

437

438

439

440

441

Mangialajo L, Chiantore M, Susini ML, Meinesz A, Cattaneo-Vietti R, Thibaut T. Zonation patterns and interspecific relationships of fucoids in microtidal environments. J Exp Mar Bio Ecol. 2012; 412: 72-80. https://doi.org/10.1016/j.jembe.2011.10.031

Mancuso FP, Strain EMA, Piccioni E, De Clerck O, Sarà G, Airoldi L. Status of vulnerable Cystoseira populations along the Italian infralittoral fringe, and relationships with environmental and anthropogenic variables. Mar Poll Bull. 2018; 129(2): 762-771.

https://doi.org/10.1016/j.marpolbul.2017.10.068

Mineur F, Arenas F, Assis J, Davies AJ, Engelen AH, Fernandes F, Malta E-J, Thibaut T, Van Nguyen T, Váz-Pinto F, Vranken S, Serrao EA, De Clerk O. European seaweeds under pressure: Consequences for communities and ecosystem functioning. J Sea Res. 2015; 98: 91-108.

https://doi.org/10.1016/j.seares.2014.11.004

Perkol-Finkel S, Airoldi L. Loss and recovery potential of marine habitats: an experimental study of factors maintaining resilience in subtidal algal forests at the Adriatic Sea. PLoS ONE. 2010; 5(5): e10791. https://doi.org/10.1371/journal.pone.0010791

Perkol-Finkel S, Ferrario F, Nicotera V, Airoldi L. Conservation challenges in urban seascapes: promoting the growth of threatened species on coastal infrastructures. J Appl Phycol. 2012; 49(6): 1457-1466. https://doi:10.1111/j.1365-2664.2012.02204.x

Reed DC, Laur DR, Ebeling AW. Variation in algal dispersal and recruitment: the importance of episodic events. Ecol Monogr. 1988; 58(4): 321-335. https://doi.org/10.2307/1942543

Rodríguez-Prieto C, Ballesteros E, Boisset F, Afonso-Carrillo J. Guía de las macroalgas y fanerógamas marinas del Mediterráneo occidental. Omega. 2013.

Sala E, Boudouresque CF, Harmelin-Vivien M. Fishing, trophic cascades, and the structure of algal assemblages: evaluation of an old but untested paradigm. Oikos. 1998; 425-439.

Sales M, Cebrian E, Tomas F, Ballesteros E. Pollution impacts and recovery potential in three species of the genus Cystoseira (Fucales, Heterokontophyta). Estuar Coast Shelf Sci. 2011; 92(3): 347-357.

Steneck RS, Graham MH, Bourque BJ, Corbett D, Erlandson JM, Estes JA, Tegner MJ. Kelp forest ecosystems: biodiversity, stability, resilience and future. Environ Conserv. 2002; 29(4): 436-459. https://doi.org/10.1017/S0376892902000322

Peer) reviewing PDF | (2019:02:34961:2:1:NEW 4 Jun 2019) 
442

443 Susini ML, Mangialajo L, Thibaut T, Meinesz A. Development of a transplantation technique of 444 Cystoseira amentacea var. stricta and Cystoseira compressa. Hydrobiologia. 2007; 580(1): 241445 244. https://doi.org/10.1007/s10750-006-0449-9

446

447 The MediTelegraph. Liguria hit by record-breaking storm surge. [cited 2018 Nov 08]. Available 448 from: http://www.themeditelegraph.com/en/shipping/2018/11/08/liguria-hit-record-breaking-

449 storm-surge-zs6juoPVgGkXvBWQJL9KuJ/index.html

450

451

452

453

454

455

456

457

458

459

460

461

462

463

464

465

466

467

468

469

470

471

472

473

474

475

476

477

478

479

480

481

Thibaut T, Pinedo S, Torras X, Ballesteros E. Long-term decline of the populations of Fucales (Cystoseira spp. and Sargassum spp.) in the Alberes coast (France, North-western Mediterranean). Mar Poll Bull. 2005; 50(12): 1472-1489.

Thibaut T, Blanfuné A, Markovic L, Verlaque M, Boudouresque CF, Perret-Boudouresque M, Mácic V, Bottin L. Unexpected abundance and long-term relative stability of the brown alga Cystoseira amentacea, hitherto regarded as a threatened species, in the north-western

Mediterranean Sea. Mar Poll Bull. 2014; 89(1-2): 305-323.

https://doi.org/10.1016/j.marpolbul.2014.09.043

Thompson RC, Wilson BJ, Tobin ML, Hill AS, Hawkins SJ. Biologically generated habitat provision and diversity of rocky shore organisms at a hierarchy of spatial scales. J Exp Mar Biol Ecol. 1996; 202(1): 73-84. https://doi.org/10.1016/0022-0981(96)00032-9

Thrush SF, Chiantore M, Asnaghi V, Hewitt J, Fiorentino D, Cattaneo-Vietti R. Habitatdiversity relationships in rocky shore algal turf infaunal communities. Mar Ecol Prog Ser. 2011; 424: 119-132. https://doi.org/10.3354/meps08960

Vásquez JA, Tala F. Repopulation of intertidal areas with Lessonia nigrescens in northern Chile. J Appl Phycol. 1995; 7(4): 347-349. https://doi.org/10.1007/BF00003791

Verdura J, Sales M, Ballesteros E, Cefalì ME, Cebrian E. Restoration of a canopy-forming alga based on recruitment enhancement: methods and long-term success assessment. Front Plant Sci. 2018; 9: 1832. https://doi.org/10.3389/fpls.2018.01832

Vergés A, Steinberg PD, Hay ME, Poore AG, Campbell AH, Ballesteros E, Kenneth LH, Booth DJ, Coleman MA, Feary DA, Figueira W, Langlois T, Marzinelli EM, Mizerek T, Mumby PJ, Nakamura Y, Roughan M, van Sebille E, Sen Gupta A, Smale DA, Tomas F, Wernberg T, Wilson SK. The tropicalization of temperate marine ecosystems: climate-mediated changes in herbivory and community phase shifts. Proc R Soc Lond B Biol Sci. 2014; 281(1789):

20140846. https://doi.org/10.1098/rspb.2014.0846

Peer) reviewing PDF | (2019:02:34961:2:1:NEW 4 Jun 2019) 
482

483 Whitaker SG, Smith JR, Murray SN. Reestablishment of the Southern California rocky intertidal

484 brown alga, Silvetia compressa: an experimental investigation of techniques and abiotic and

485 biotic factors that affect restoration success. Restor Ecol. 2010; 18: 18-26.

486 https://doi.org/10.1111/j.1526-100X.2010.00717.x

487

488 Yoon JT, Sun SM, Chung G. Sargassum bed restoration by transplantation of germlings grown

489 under protective mesh cage. J Appl Phycol. 2014; 26(1): 505-509.

490 https://doi.org/10.1007/s10811-013-0058-8

491

492 Yu YQ, Zhang QS, Tang YZ, Zhang SB, Lu ZC, Chu SH, Tang XX. Establishment of intertidal 493 seaweed beds of Sargassum thunbergii through habitat creation and germling seeding. Ecol Eng. 494 2012; 44: 10-17. https://doi.org/10.1016/j.ecoleng.2012.03.016 495 


\section{Figure 1 (on next page)}

Map showing the location of the culture laboratory facilities and the donor (DS) and receiving (RS) sites. 


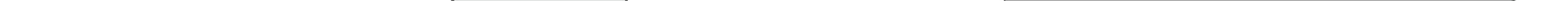




\section{Figure 2 (on next page)}

Percent cover of $C$. amentacea (average $+\mathrm{SE}$ ) on tiles when leaving the controlled growth conditions (laboratory) and at the time of positioning (outplanting) at the receiving site (72 hours later). 


\section{Figure 3 (on next page)}

Percent cover of $C$. amentacea (average $+\mathrm{SE}$ ) on the clay tiles over time (Time 0 to Time 4 ) in the eight patches at the receiving site. 


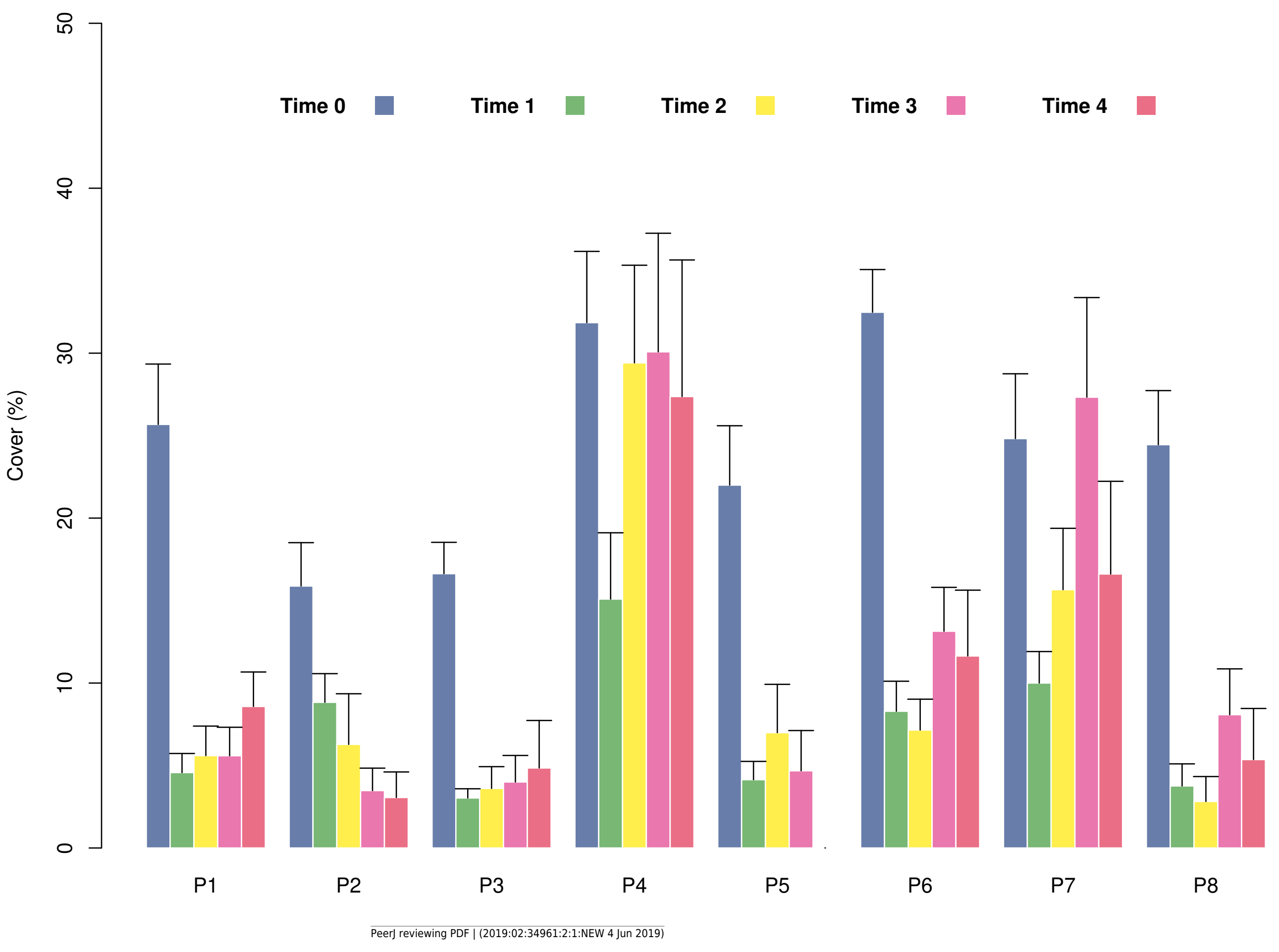




\section{Figure 4 (on next page)}

Percent cover of $C$. amentacea juveniles (average $+\mathrm{SE}$ ) in each cover class (Low-L, Medium-M, High-H) on the clay tiles over time (Time 0 to Time 4 ) at the start of the experiment. 


\section{Figure 5 (on next page)}

Percentage of tiles with $C$. amentacea juveniles over time (Time 0 to Time 4 ) according to presence/absence data for the individual tiles in the eight patches at the receiving site.

Eight patches were allocated to the different cover classes. Red dots represent average values across the patches (average $\pm \mathrm{SE}$ ). L- Low cover class; M- Medium cover class; $\mathrm{H}$ High cover class. 


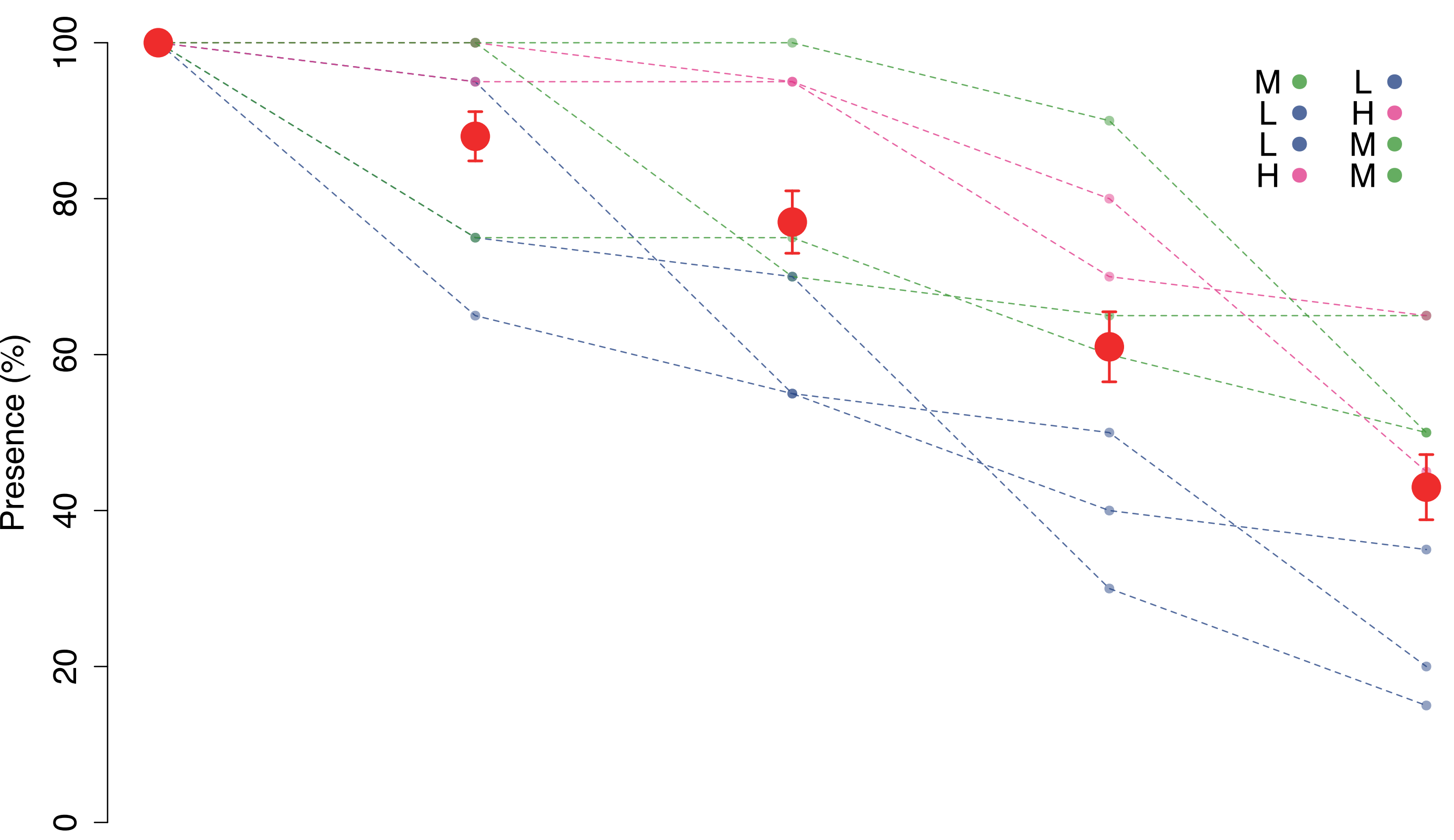


Figure 6

Development of the outplanted juveniles on tiles over time (Time 0 to Time 5) at the receiving site.

a) Juveniles leaving the lab facilities (avg: $2.67 \mathrm{~mm}$ ), b) Time 0 - outplanting day (avg: 3.22 $\mathrm{mm}$ ), c) Time 1 - one week (avg: $3.73 \mathrm{~mm}$ ), d) Time 2 - two weeks (avg: $4.67 \mathrm{~mm}$ ), e) Time 3

- one month (avg: $6.02 \mathrm{~mm}$ ), f) Time 4 - two months (avg: $8.03 \mathrm{~mm}$ ), g-i) juveniles six months after outplanting $(3-6 \mathrm{~cm})$. 

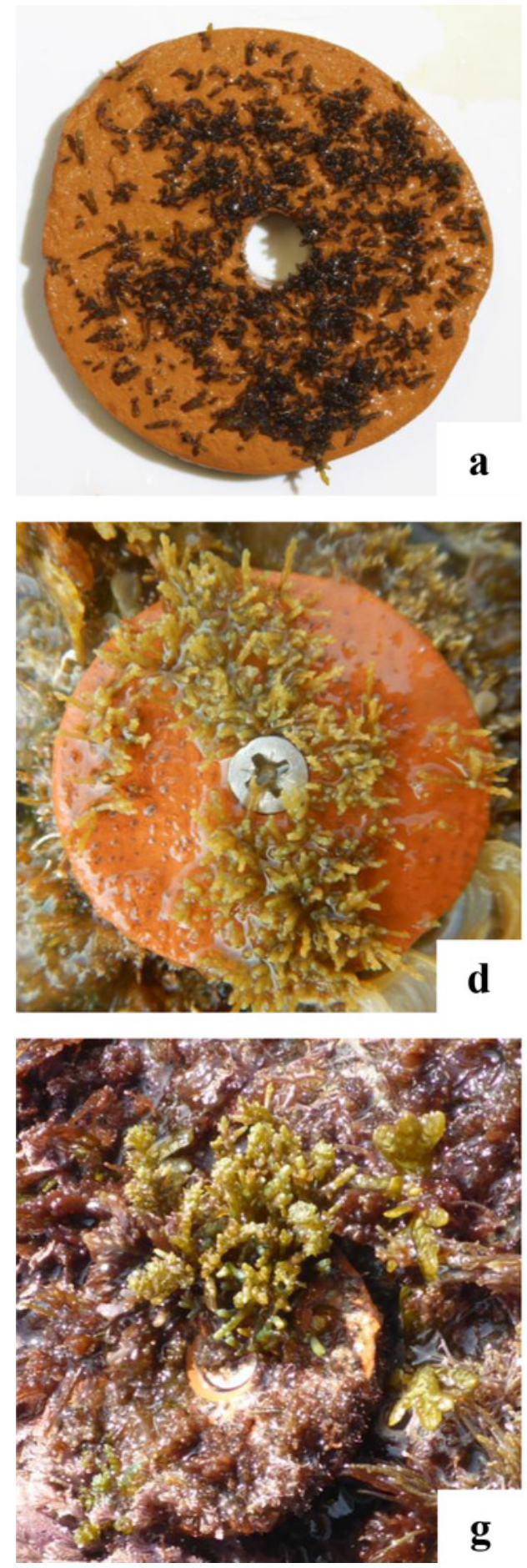

g
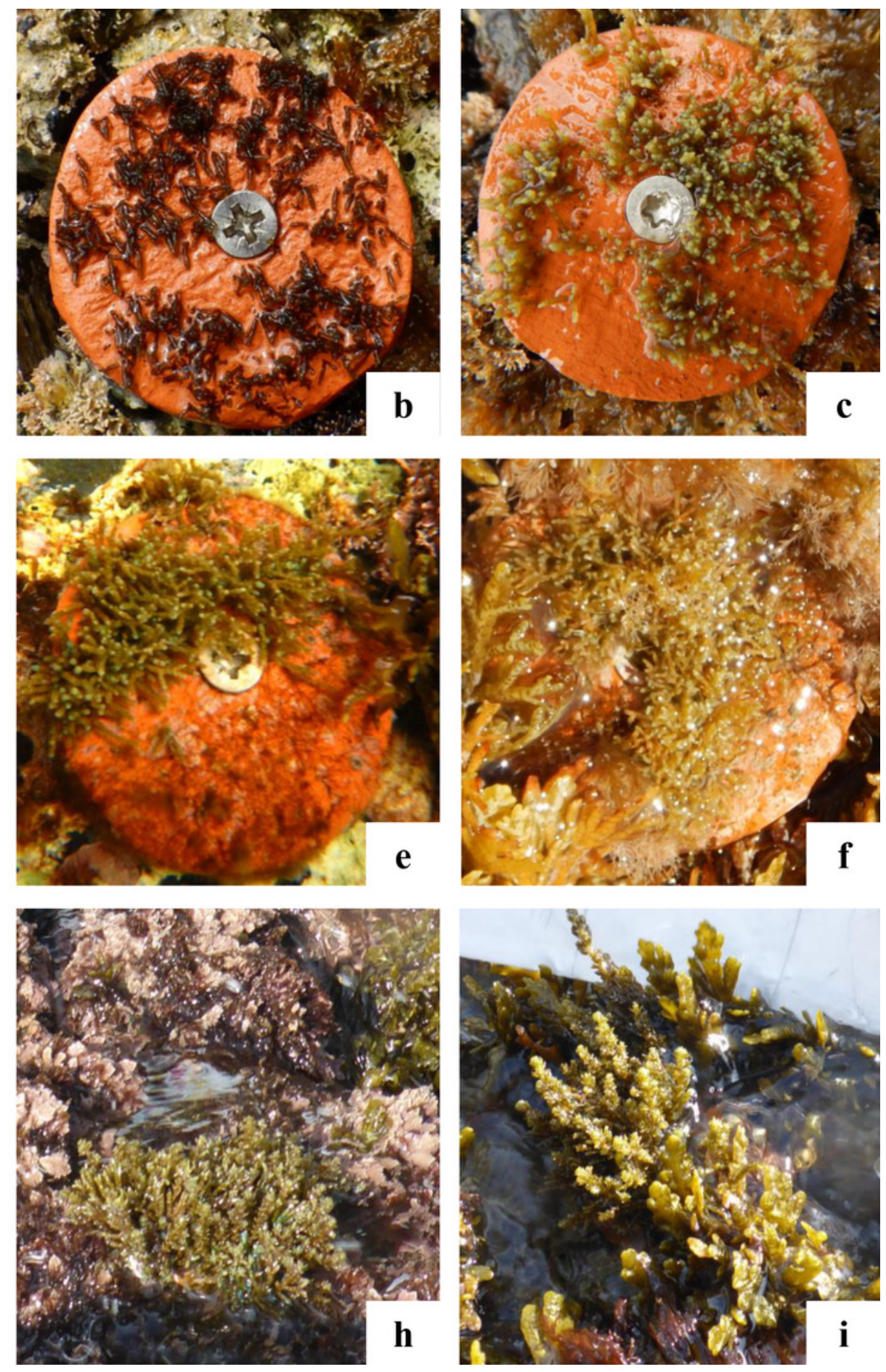
Figure 7 (on next page)

Size frequency distribution of the outplanted juveniles of Cystoseira amentacea over time. 

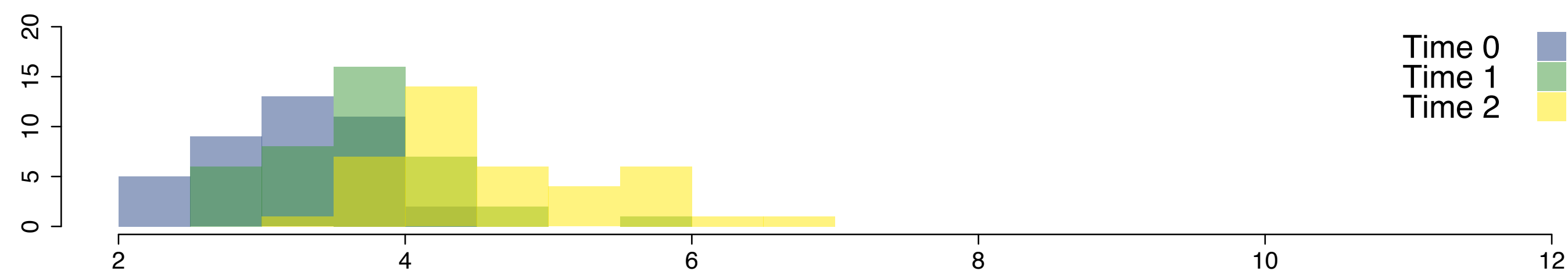

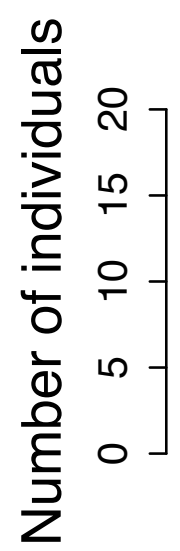

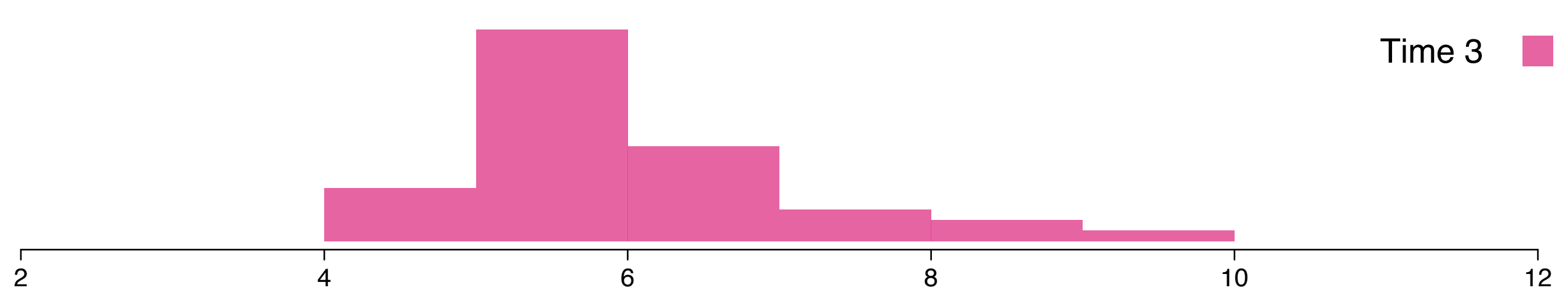

$\left.\begin{array}{c}\stackrel{N}{1} \\ \leftarrow \\ 0 \\ 0 \\ 1 \\ 0 \\ 0\end{array}\right]$

Time 4

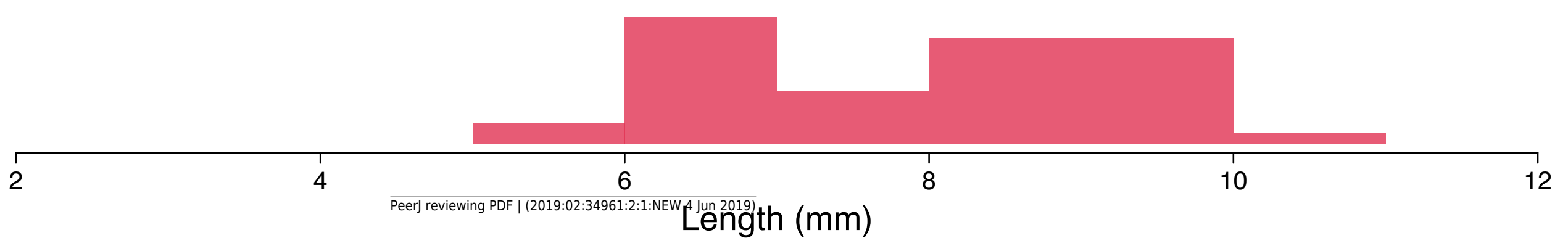




\section{Table $\mathbf{1}$ (on next page)}

Results of the GLMs of the differences in percent cover and presence/absence of juveniles of the cover classes (Low, Medium, High) at Time 4 . 


\begin{tabular}{|c|c|c|c|c|c|}
\hline \multirow[t]{4}{*}{ presence/absence } & & Estimate & Std. error & z-value & $\operatorname{Pr}(>|z|)$ \\
\hline & High - Medium & 0.05084 & 0.28864 & 0.176 & 0.98288 \\
\hline & High - Low & -0.99550 & 0.36378 & -2.373 & $0.01689 *$ \\
\hline & Medium - Low & 1.04634 & 0.32695 & 3.200 & $0.00387 * *$ \\
\hline percemt cover & High - Medium & -0.8179 & 0.3683 & -2220 & 00652 \\
\hline & High - Low & -2.2942 & 0.5732 & -4.003 & $<0.001 * * *$ \\
\hline & Medium - Low & 1.4763 & 0.5642 & 2.617 & $0.0231 *$ \\
\hline
\end{tabular}

1 